\title{
TRANSMYOCARDIAL REVASCULARIZATION FOR CARDIAC TRANSPLANTATION ALLOGRAFT VASCULOPATHY
}

P. Michael McFadden, MD, Robert J. Robbins, MD, John L. Ochsner, MD, Clifford H. Van Meter, MD, and Susan Majorie, RN, New Orleans, La.

Cardiac allograft vasculopathy is a leading cause of death after heart transplantation. ${ }^{1}$ Virtually all cardiac transplant recipients exhibit some histopathologic evidence of vasculopathy 1 year after transplantation. ${ }^{2}$ Management options for patients with myocardial ischemia caused by this condition have been limited to medical therapy, coronary revascularization, or cardiac retransplantation. To determine whether transmyocardial laser revascularization (TMR) is an effective treatment for cardiac allograft vasculopathy after cardiac transplantation, we performed holmium laser revascularization on four patients with myocardial ischemia who met research protocol criteria.

\section{Clinical summaries}

PATIENT 1. A 60-year-old man had angina and exertional dyspnea 35 months after heart transplantation for ischemic cardiomyopathy. Coronary angiography demonstrated allograft vasculopathy. Percutaneous transluminal coronary angioplasty of the left anterior descending system and stenting of the right coronary artery provided transient relief of symptoms. Recurrent angina 1 year later prompted cardiac catheterization, which revealed diffuse vasculopathy. A dipyridamole thallium perfusion study revealed reversible global ischemia. TMR and triple-vessel coronary artery bypass were performed 62

From the Division of Thoracic and Cardiovascular Surgery, Department of Surgery, Ochsner Clinic and Alton Ochsner Medical Foundation, New Orleans, La.

Received for publication Sept. 16, 1997; accepted for publication Dec. 15, 1997.

Address for reprints: P. Michael McFadden, MD, Ochsner Clinic, 1514 Jefferson Highway, New Orleans, LA 70121.

J Thorac Cardiovasc Surg 1998;115:1385-8

Copyright (c) 1998 by Mosby, Inc.

0022-5223/98 $\$ 5.00+0 \quad \mathbf{1 2 / 5 4 / 8 8 2 0 5}$ months after transplantation (Table I). Recovery was uneventful and the patient remained free of symptoms. The marked improvement noted on the initial 3-month postoperative dipyridamole thallium perfusion study was sustained on repeated studies 6 and 18 months after the operation. Improvement in perfusion was apparent in both bypassed and lased areas of myocardium.

PATIENT 2. A 54-year-old woman began having angina 22 months after transplantation for ischemic cardiomyopathy. Her symptoms were initially relieved with nitrates, but recurrent angina prompted angiography, which revealed nonbypassable allograft vasculopathy. A dipyridamole thallium perfusion study demonstrated significant reversible ischemia. TMR was performed to areas of ischemic myocardium (Table I). After the operation the patient was angina free. She had marked and sustained improvement in perfusion to the anterior and anterolateral walls on dipyridamole thallium studies 3 and 6 months after the procedure (Fig. 1). The patient remained free of symptoms and active until her death from a myocardial infarction 10 months after TMR.

PATIENT 3. A 52-year-old man began having angina 24 months after heart transplantation for ischemic cardiomyopathy. Coronary angiography performed 1 year later demonstrated proximal atherosclerotic stenoses and diffuse allograft vasculopathy. Percutaneous transluminal coronary angioplasty of a proximal stenosis of the left anterior descending coronary artery provided temporary relief, but class IV angina symptoms recurred within 1 year. A second angiogram revealed diffuse allograft vasculopathy and significant proximal triple-vessel disease. Dobutamine-stress echocardiography induced severe angina and produced little alteration in impaired allograft function. TMR was performed to the area of myocardium supplied by the nonbypassable left anterior descending and diagonal coronary arteries, and concomitant coronary bypass was performed to the circumflex and right coronary systems 61 months after transplantation (Table I). Recovery was uneventful and the patient was angina free. 


\section{Preoperative}

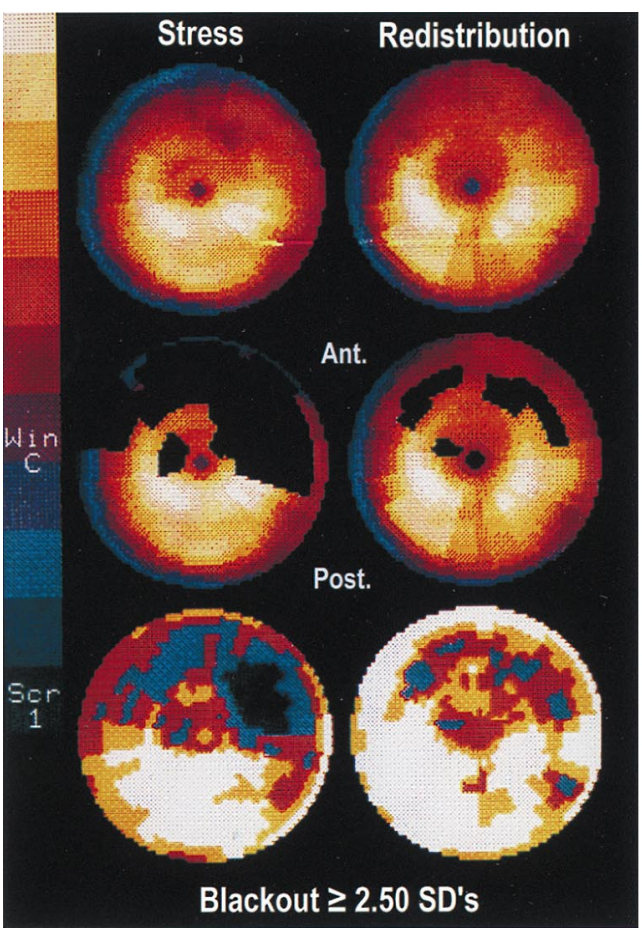

\section{Post operative}

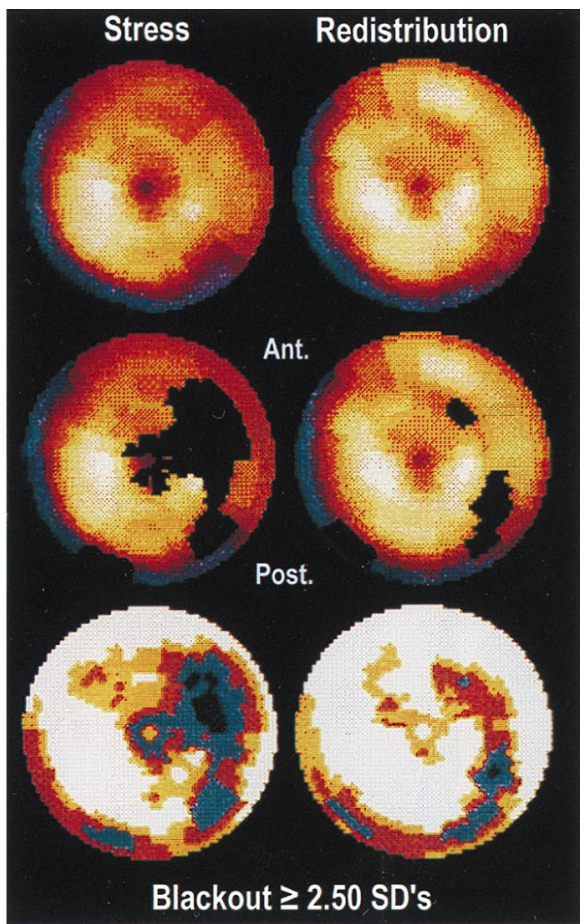

Fig. 1. Stress dipyridamole thallium perfusion study (left) demonstrating markedly decreased perfusion of the anterior and lateral walls in a patient with cardiac allograft vasculopathy. Postoperative study 3 months after TMR (right) demonstrates essentially normal myocardial perfusion.

Table I. Initial series of cardiac transplant recipients with allograft vasculopathy treated with TMR

\begin{tabular}{|c|c|c|c|c|c|c|c|c|c|}
\hline \multirow[b]{2}{*}{ Patient } & \multicolumn{2}{|c|}{$C H F^{*}$} & \multicolumn{2}{|c|}{ Angina $\dagger$} & \multicolumn{3}{|c|}{ Perfusion study } & \multirow{2}{*}{$\begin{array}{c}\text { TMR } \\
\text { (location and no.) }\end{array}$} & \multirow{2}{*}{$\begin{array}{c}C A B G \\
\text { (no. and site) }\end{array}$} \\
\hline & Pre & Post & Pre & Post & Pre & 3 or 4 months & 6 months & & \\
\hline 1 & 0 & 0 & III & 0 & $\begin{array}{l}\text { Large reperfusion } \\
\text { defect in ant-sept, } \\
\text { apex, and inf-lat } \\
\text { regions }\end{array}$ & $\begin{array}{l}\text { Small reperfusion } \\
\text { defect in ant-sept } \\
\text { and inf-lat regions }\end{array}$ & $\begin{array}{l}\text { Same as at } 3 \text { months. } \\
\text { New reperfusion } \\
\text { defect in ant-lat } \\
\text { region }\end{array}$ & $\begin{array}{l}\text { Anterior } 2 \\
\text { Ant-lat } 5 \\
\text { Post-lat } 6 \\
\text { Apex } 2 \\
\text { Inferior } 2\end{array}$ & $\begin{array}{l}\text { LITA-LAD } \\
\text { SVG-PDA } \\
\text { SVG-OM }\end{array}$ \\
\hline 2 & I & I & IV & 0 & $\begin{array}{l}\text { Large reperfusion } \\
\text { defect in ant, ant- } \\
\text { lat, and inf regions }\end{array}$ & $\begin{array}{l}\text { Decreased reperfu- } \\
\text { sion defect in ant, } \\
\text { ant-lat, and inf } \\
\text { regions }\end{array}$ & Similar to 3 months & $\begin{array}{l}\text { Anterior } 13 \\
\text { Ant-lat } 6 \\
\text { Post-lat } 5 \\
\text { Apex } 7\end{array}$ & NA \\
\hline 3 & 0 & 0 & IV & I & $\begin{array}{l}\text { Stress-induced angina } \\
(10: 10), \text { normal LV } \\
\text { function with stress }\end{array}$ & $\begin{array}{l}\text { No angina, normal } \\
\text { LV function with } \\
\text { stress }\end{array}$ & NA & $\begin{array}{l}\text { Anterior } 9 \\
\text { Ant-lat } 5 \\
\text { Apex } 4\end{array}$ & $\begin{array}{l}\text { SVG-OM } \\
\text { SVG-RCA }\end{array}$ \\
\hline 4 & III & III & IV & $0-\mathrm{I}$ & $\begin{array}{l}\text { Improved LV func- } \\
\text { tion with stress, } \\
\text { + viability inf, ant, } \\
\text { and septal regions }\end{array}$ & $\begin{array}{l}\text { Improved LV func- } \\
\text { tion with stress, } \\
\text { decrease in hypo- } \\
\text { kinesis regions of } \\
\text { LV }\end{array}$ & NA & $\begin{array}{l}\text { Anterior } 10 \\
\text { Ant-lat } 7 \\
\text { Post-lat } 3 \\
\text { Apex } 7\end{array}$ & NA \\
\hline
\end{tabular}

$C H F$, Congestive heart failure; $C A B G$, coronary artery bypass graft; $L I T A$, left internal thoracic artery; $L A D$, left anterior descending; $S V G$, saphenous vein graft; $P D A$, posterior descending artery; $O M$, obtuse marginal coronary artery; $N A$, not applicable; $L V$, left ventricular (ventricle); $R C A$, right coronary artery; ant, anterior; lat, lateral; inf, inferior; post, posterior; sept, septal.

* New York Heart Association Heart Failure classification.

$\dagger$ Canadian Cardiovascular Society anginal score. 
Dobutamine-stress echocardiography induced no angina, and left ventricular function was normal with stress 4 months after the operation. Fourteen months after TMR the patient reported mild class II angina symptoms.

PATIENT 4. A 64-year-old man with ischemic cardiomyopathy began having symptoms of heart failure 49 months after heart transplantation. He was treated medically for 2 years before severe class IV angina and persistent heart failure prompted evaluation. Coronary angiography revealed diffuse allograft vasculopathy that was not amenable to coronary revascularization. Dobutamine-stress echocardiography documented enhanced allograft left ventricular function with stress and indicated anterior, inferior, and septal wall viability. The patient underwent TMR of the ischemic myocardium 50 months after transplantation (Table I). After the operation the patient had relief of angina but continued to experience symptoms of class III heart failure. Dobutamine-stress echocardiography performed 4 months after the operation demonstrated an overall improvement in allograft function with stress, particularly in areas that were more severely hypokinetic. His status was stable 14 months after TMR.

Discussion. TMR has yielded favorable early and intermediate-term relief of angina in patients with otherwise inoperable coronary artery disease. ${ }^{3-6}$ In addition, improvement in left ventricular ejection fraction, wall motion, and relative subendocardial perfusion have been recently demonstrated. ${ }^{5}$ Whether the response to TMR is due to creation of intramyocardial channels, initiation of angiogenesis and neovascularization, or alteration in pain perception resulting from a denervation phenomenon has not been established. Despite uncertainties regarding the exact mechanism by which TMR is effective, favorable results observed in these patients prompted us to use laser revascularization in cardiac transplant recipients with myocardial ischemia caused by severe allograft vasculopathy.

Two distinct lesions have been described angiographically in cardiac allograft vasculopathy. ${ }^{1,2}$ Atheromatous lesions of the proximal and middle thirds of the coronary arteries, similar in distribution to native coronary artery disease, have been termed type A lesions. In contrast, type B lesions are described as long, obliterative, tubular lesions within the distal third of the coronary arteries. Type B lesions result from intimal fibroproliferation and represent the most common vascular lesion encountered after heart transplantation. Immunologic and traditional risk factors are likely co-contributors to cardiac allograft vasculopathy. ${ }^{7,8}$

Treatment options available for patients with type A lesions are medical therapy, coronary bypass, angioplasty, coronary stenting, or cardiac retransplantation. Most patients, however, display both type A and type B coronary lesions, and adequate treatment may best be achieved with a combined procedure such as direct coronary revascularization and TMR. This poses a problem in evaluating the efficacy of TMR. The role for TMR will best be delineated in patients with nonreconstructable coronary vascular disease who are not candidates for cardiac retransplantation and who undergo TMR alone.
Cardiac transplant recipients are a challenging group to follow up objectively. Patients with accelerated coronary allograft vasculopathy are commonly symptom free and frequently present with congestive heart failure, arrhythmias, silent myocardial infarction, or sudden death. Inasmuch as posttransplantation vasculopathy is a common cause of death after cardiac transplantation, ${ }^{1}$ routine heart catheterization and coronary arteriography to monitor these patients is recommended. Coronary arteriography has been the best means of establishing the presence of allograft vasculopathy. However, the utility of arteriography is limited in the presence of type B lesions because the extent of disease is often underestimated. Dipyridamole thallium studies were useful in identifying two of our patients with viable myocardium who would benefit from TMR, as well as in evaluating the postoperative response. Intracoronary ultrasonography, although not used in our patients, may prove useful to corroborate or further evaluate the progression of this disease. Recent evidence indicates that dobutamine-stress echocardiography may be superior to dipyridamole thallium studies in screening for allograft vasculopathy, because the former is not influenced by the blunted chronotropic response to adrenergic stimulation commonly observed in transplanted hearts. ${ }^{9}$

Cardiac allograft vasculopathy remains a leading cause of death in the heart transplant population. Very few treatment options exist for this form of accelerated atherosclerosis. Laser revascularization has demonstrated favorable early results and may serve as a viable alternative for patients with allograft vasculopathy who are unresponsive to medical management and who are not candidates for coronary revascularization or cardiac retransplantation. The long-term results of this procedure in cardiac allograft vasculopathy await further study and analysis.

\section{REFERENCES}

1. Johnson DE, Alderman EL, Schroeder JS, Gao SZ, Hunt S, DeCampli WM, et al. Transplant coronary artery disease: histopathologic correlations with angiographic morphology. J Am Coll Cardiol 1991;17:449-57.

2. Johnson DE, Gao SZ, Schroeder JS, DeCampli WM, Billingham ME. The spectrum of coronary artery pathologic findings in human cardiac allografts. J Heart Transplant 1989;8:349-59.

3. Horvath KA, Cohn LH, Cooley DA, Crew JR, Frazier OH, Griffith BP, et al. Transmyocardial laser revascularization: results of a multicenter trial with transmyocardial laser revascularization used as a sole therapy for end-stage coronary artery disease. J Thorac Cardiovasc Surg 1997;113:645-54.

4. Horvath KA, Mannting F, Cummings N, Shernan SK, Cohn LH. Transmyocardial laser revascularization: operative techniques and clinical results at two years. J Thorac Cardiovasc Surg 1996;111:1047-53.

5. Frazier OH, Cooley DA, Kadipasaoglu KA, Pehlivanoglu S, Lindenmeir M, Barasch E, et al. Myocardial revascularization with laser: preliminary findings. Circulation 1995;92(Suppl) II58-65.

6. Cooley DA, Frazier OH, Kadipasaoglu KA, Lindenmeir MH, Pehlivanoglu S, Kolff JW, et al. Transmyocardial laser revascularization: clinical experience with twelve-month follow-up. J Thorac Cardiovasc Surg 1996;111:791-9. 
7. Petrossian GA, Nichols AB, Marboe CC, Sciacca R, Rose EA, Smith CR, et al. Relation between survival and development of coronary artery disease and anti-HLA antibodies after cardiac transplantation. Circulation 1989;80(Suppl):III122-5.

8. Gao SZ, Schroeder JS, Alderman EL, Hunt SA, Silverman JF, Wiederhold V, et al. Clinical and laboratory correlates of accelerated coronary artery disease in the cardiac transplant patient. Circulation 1987;76(Suppl):V56-61.

9. Akosah KO, Mohanty PK, Funai JT, Jesse RL, Minisi AJ, Crandall $\mathrm{CW}$, et al. Noninvasive detection of transplant coronary artery disease by dobutamine stress echocardiography. J Heart Lung Transplant 1994;13:1024-38. 